\title{
Primary Small Cell Carcinoma of Liver: A Rare Tumor
}

\author{
Lileswar Kaman ${ }^{\mathrm{a}, \mathrm{c}}$, Javid Iqbal ${ }^{\mathrm{a}}$, Mahander Palla, Amanjit Bal ${ }^{\mathrm{b}}$
}

\begin{abstract}
Primary small cell carcinoma of the liver is very rare tumor. Till date only 12 cases have been reported in the English literature. We are reporting a case of primary small cell carcinoma of the liver in a female patient. She had $13 \mathrm{~cm} \times 7 \mathrm{~cm}$ tumor in the right lobe of liver and fine needle aspiration cytology revealed features of small cell carcinoma. After ruling primary from elsewhere, patient underwent central bisectionectomy of the liver and histopathology confirmed the diagnosis of primary small cell carcinoma of the liver. On immunohistochemistry examination, the tumor was positive for Neuron-specific enolase and synaptophysin but negative for Thyroid transcription factor 1 and Hep-Par 1. Here we discuss the clinical course and treatment of primary small cell carcinoma of the liver in our case and review the literature.
\end{abstract}

Keywords: Primary small cell carcinoma liver; Liver tumor; Bisectionectomy of liver

\section{Introduction}

Majority of small cell carcinomas (SCC) are located in the lungs, which account for $25 \%$ of lung carcinomas $[1,2]$. About $2 \%-4 \%$ of small cell carcinomas have been reported from extrapulmonary organs, including esophagus, thymus, stomach, pancreas and cervix [1-3]. These are diagnosed as extrapulmonary small cell carcinomas (EPSCC). Almost

Manuscript accepted for publication June 18, 2010

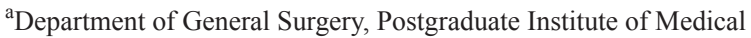
Education and Research, Chandigarh-160012, India

${ }^{\mathrm{b}}$ Department of Histopathology, Postgraduate Institute of Medical

Education and Research, Chandigarh-160012, India

${ }^{\mathrm{c} C}$ Corresponding author: General Surgery, PGIMER,

Chandigarh-160012, India. Email: kamanlil@yahoo.com
}

doi:10.4021/gr2010.06.215w half of the EPSCC are localized in the gastrointestinal tract [2-3]. The occurrence of EPSCC in other organs is considered to be rare [1-3]. Primary small cell carcinoma (PSSC) of the liver is very rare entity and only 12 cases have been reported worldwide. We report a case of 40-year-old female patient with primary small cell carcinoma of the liver.

\section{Case Report}

A 40 years old female patient presented with pain upper abdomen, mild to moderate in intensity for 40 days and lump upper abdomen for 10 days. She had history of loss of weight and appetite, but there was no history of cough, fever, jaundice or oral contraceptive intake. On examination, patient was thin built, afebrile, non icteric and hemodynamically stable. Chest and cardiovascular examination were within normal limits. Hepatomegaly was present with an $8 \mathrm{~cm} \times 7 \mathrm{~cm}$ lump in the epigastric region. There was

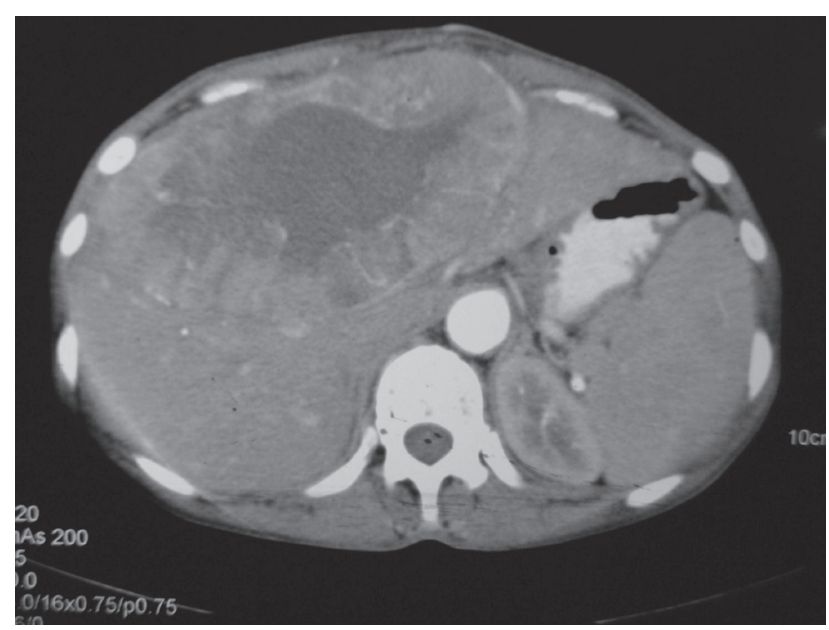

Figure 1. Contrast enhanced computed tomography (CECT) abdomen revealed $13.2 \times 13.5 \times 7.3 \mathrm{~cm}$ well defined mass lesion involving segment IV, V and VIII of liver. There was rim enhancement on arterial phase and no contrast retention on venous phase. 

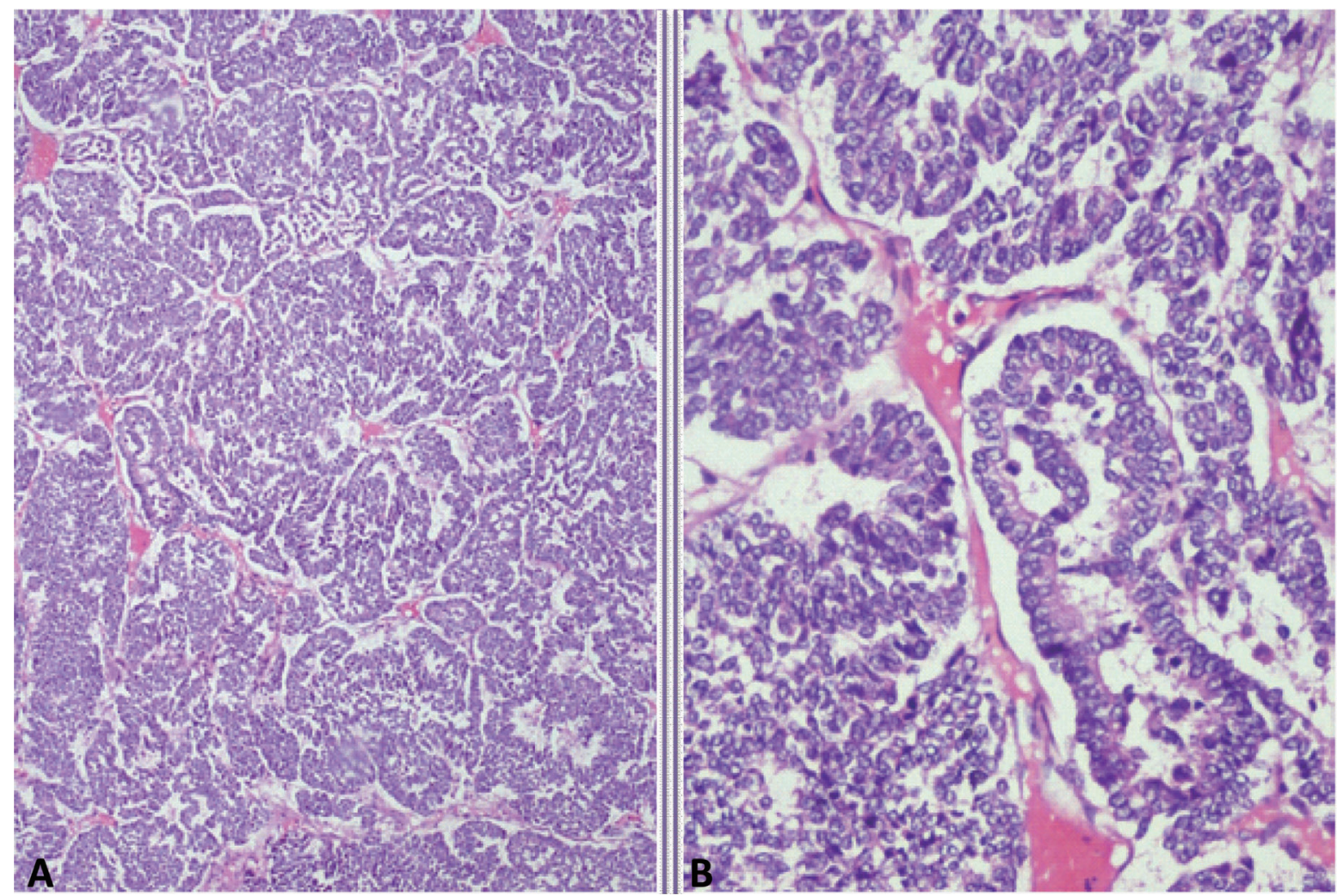

Figure 2. Photomicrograph showing A: Organoid and trabecular pattern of tumor cells separated by thin fibrovascular septa; $B$ : Tumor cells with finely granular nuclear chromatin and scanty cytoplasm (Haematoxylin and eosin, x 100, x 400).

no ascites and rectal examination was within normal limit. On laboratory examination, the hemoglobin was $9.8 \mathrm{gm} \%$, serum bilirubin was $0.24 \mathrm{gm} \%$, AST and ALT were 63/53 IU, alkaline phosphate was $572 \mathrm{IU}$, albumin was $3.5 \mathrm{gm} \%$, PTI was $100 \%$, Alpha Feto Protein was $2.11 \mathrm{ng} / \mathrm{dl}$ and CEA level was $1.0 \mathrm{ng} / \mathrm{ml}$, which were all within the normal limits. Contrast enhanced computed tomography (CECT) abdomen revealed $13.2 \times 13.5 \times 7.3 \mathrm{~cm}$ well defined mass lesion involving segment IV, V and VIII of liver (Fig. 1). There was rim enhancement on arterial phase and no contrast retention on venous phase. Lesion was compressing the right and left branches of portal vein and there was no ascites. Tumor was involving $58.37 \mathrm{~cm}^{2}(38.68 \%)$ of the total liver volume. Fine needle aspiration cytology (FNAC) showed features of small cell carcinoma the liver. Upper and lower gastrointestinal endoscopy were normal. Chest x-ray, sputum cytology, chest CECT and bronchoscopy were normal. Positron Emission Tomography (PET) scan revealed 14 $\mathrm{x} 10 \mathrm{~cm}$ mass lesion in liver with metabolic active disease at periphery and central necrosis. No other hypermetabolic lesions elsewhere in body were seen. Patient underwent laparotomy and central bisectionectomy for the tumor arising from segment IV, V and VIII of liver. Histology showed tumor arranged in lobules, nests and trabecular pattern (Fig. 2). Cells were mildly pleomorphic with hyperchromatic nucleus, scanty cytoplasm and many mitotic figures. Features were suggestive of primary small cell carcinoma of the liver. Portal lymph nodes showed metastatic disease. On immunohistochemistry, tumor was positive for neuronspecific enolase and synaptophysin but negative for thyroid transcription factor 1, hep-Par 1 and carcinoembryonic antigen (Fig. 3). Patient recovered well in postoperative period, and was discharged on postoperative day 7 . Now patient is on follow-up and undergoing combined chemotherapy.

\section{Discussion}

Since its initial description by Duguid and Kennedy in 1930, extrapulmonary small cell carcinoma (EPSCC) is recognized as a clinicopathological entity distinct from small cell carcinoma of the lung [4-5]. EPSCC have been reported to occur in $0.1 \%-0.4 \%$ of all malignancies $[1-3,6-7]$. It has been recognized as a distinct clinical entity and has been reported in several organs other than the lung over the past 30 years. Primary locations include the head, neck, salivary glands, 

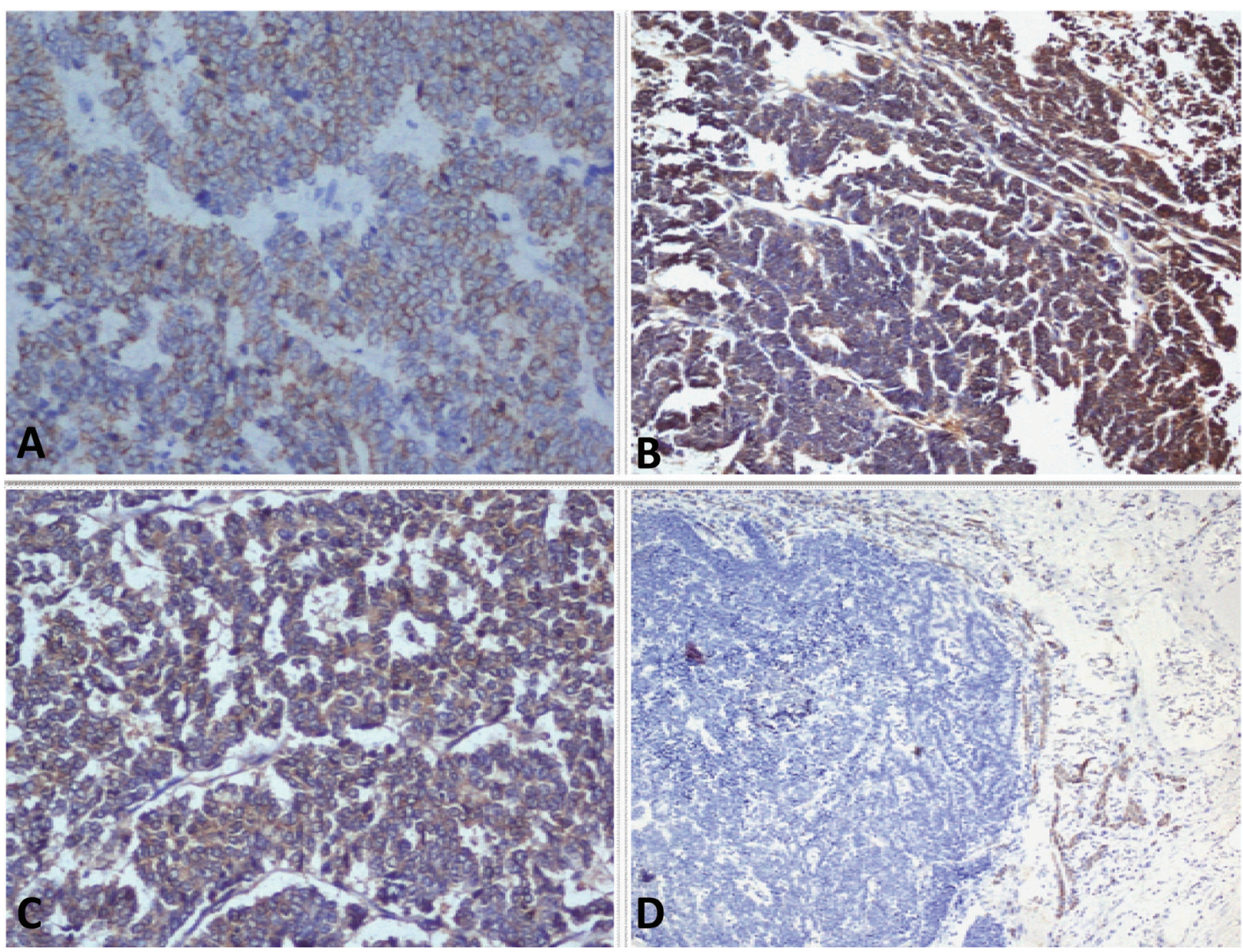

Figure 3. A-D: Photomicrograph showing A: Pancytokeratin positivity; B: Neuron specific enolase positivity; C: Synaptophysin positivity and D: Hep Par-1 negativity in tumor cells (Immunostains, x 200).

thyroid, larynx, trachea, thymus, pleura, esophagus, stomach, intestines, rectum, pancreas, gall bladder, cervix, uterus, breast, prostate, urinary bladder, and skin [1-3]. In order to distinguish EPSCC from metastatic pulmonary small cell carcinomas, patient should have normal chest radiograph, computed tomography (CT) scan of the chest, sputum cytology, and negative bronchoscopy or PET scan. Primary small cell carcinoma of the liver (PSCCL) is very rare and only 12 cases have been described in the literature until now (Table 1). Zanconati et al [8] reported 3 cases, one patient was treated by mass resection but the others received no therapy. The clinical progression was rapid and death ensued between 1 and 5 months after diagnosis. In the two cases reported by Sengoz et al [9], one patient who received chemotherapy survived for 13 months and the other survived for 67 months after hemihepatectomy. Kim et al [10] reported a case in which segmentectomy of the liver and adjuvant chemotherapy were performed, the patient survived with no signs of recurrence for at least 4 months. In other 5 reported cases, 2 patients received combined chemotherapy [11, 12], and two underwent resection $[13,14]$ and one received no treatment [2]. Choi et al [12] reported that primary small cell cancer of liver expresses c-kit, a stem cell marker of the liver. Morikawa et al [15] reported a case of primary small cell liver which was treated with chemotherapy with good outcome. In our patient tumor was arising from segment IV, $\mathrm{V}$ and VIII of liver and underwent central bisectionectomy followed by combined chemotherapy and is doing well. The patients of primary small cell cancer of liver, who underwent radical operation and chemotherapy, had better outcome. The regimens of chemotherapy consisted of platinum-based combination therapy. Because of the small number of cases reported till date, it is difficult to make any definite recommendation regarding the best possible treatment for primary 
Table 1. Clinicopathological and Immunohistochemical Features of Patients With Primary Small Cell Carcinoma of the Liver

\begin{tabular}{|c|c|c|c|c|c|c|c|}
\hline Author & $\begin{array}{l}\text { Age / } \\
\text { Sex }\end{array}$ & Symptom & $\begin{array}{l}\text { Size } \\
(\mathrm{cm})\end{array}$ & $\begin{array}{l}\text { Stage of } \\
\text { Disease }\end{array}$ & $\begin{array}{l}\text { AFP } \\
(\mathrm{ng} / \mathrm{ml})\end{array}$ & $\begin{array}{l}\text { Immunohistochemical } \\
\text { Staining }\end{array}$ & Treatment \\
\hline $\begin{array}{l}\text { Ryu et al } \\
{[11]}\end{array}$ & $56 / \mathrm{M}$ & $\begin{array}{l}\text { RUQ pain, } \\
\text { general } \\
\text { weakness }\end{array}$ & $8 \mathrm{~cm}$ & Advanced & 3.24 & $\begin{array}{l}\text { (+) CD56, C-kit, SYN; } \\
\text { (-) TTF-1 }\end{array}$ & $\begin{array}{l}\text { CT (cisplatin, } \\
\text { etoposide, } \\
\text { irinotecan) }\end{array}$ \\
\hline $\begin{array}{l}\text { Kim et al } \\
{[10]}\end{array}$ & $53 / \mathrm{M}$ & Palpable mass & $12 \mathrm{~cm}$ & Advanced & 2.94 & $\begin{array}{l}(+) \text { CD56, NSE, C-kit, SYN, } \\
\text { mixed CK, EMA; } \\
\text { (-) CK7, 8, 19, 20, AFP, CEA, } \\
\text { hepatocyte, vimentin, desmin, } \\
\text { TTF-1 }\end{array}$ & $\begin{array}{l}\text { Segmentectomy } \\
\text { and CT (cisplatin, } \\
\text { etoposide) }\end{array}$ \\
\hline $\begin{array}{l}\text { Zanconati } \\
\text { et al [8] }\end{array}$ & $56 / \mathrm{M}$ & $\begin{array}{l}\text { Abdominal } \\
\text { discomfort }\end{array}$ & $5 \mathrm{~cm}$ & Limited & $>200$ & $\begin{array}{l}\text { (+) AE1/AE3, CK8, 18, 19, } \\
\text { NSE, AFP, ERY-1; } \\
\text { (-) S-100 protein, CEA }\end{array}$ & Partial hepatectomy \\
\hline $\begin{array}{l}\text { Zanconati } \\
\text { et al [8] }\end{array}$ & $69 / \mathrm{M}$ & $\begin{array}{l}\text { DM, weight } \\
\text { loss }\end{array}$ & $10 \mathrm{~cm}$ & Advanced & - & $\begin{array}{l}\text { (+) AE1/AE3, CK 8, 18, 19; } \\
(+/-) \text { NSE, CHR; } \\
\text { (-) S-100 protein, CEA }\end{array}$ & - \\
\hline $\begin{array}{l}\text { Zanconati } \\
\text { et al [8] }\end{array}$ & $89 / \mathrm{M}$ & Jaundice & $6 \mathrm{~cm}$ & Advanced & 150 & $\begin{array}{l}\text { (+) AE1/AE3, CK 8, 18, 19, } \\
\text { AFP, NSE; } \\
\text { (-) CHR, S-100 protein, CEA }\end{array}$ & - \\
\hline $\begin{array}{l}\text { Kim et al } \\
{[13]}\end{array}$ & $67 / \mathrm{M}$ & $\begin{array}{l}\text { Abdominal } \\
\text { discomfort }\end{array}$ & $12 \mathrm{~cm}$ & Advanced & - & $\begin{array}{l}\text { (+) SYN, CD56, C-kit; } \\
\text { (-) CK, CEA, AFP }\end{array}$ & $\begin{array}{l}\text { CT (cisplatin, } \\
\text { epirubicin) }\end{array}$ \\
\hline $\begin{array}{l}\text { Sengoz et } \\
\text { al [9] }\end{array}$ & $73 / \mathrm{F}$ & - & & Advanced & - & & Right hepatectomy \\
\hline $\begin{array}{l}\text { Sengoz et } \\
\text { al [9] }\end{array}$ & $66 / \mathrm{M}$ & - & & - & - & & CT (Cisplatin) \\
\hline $\begin{array}{l}\text { Kim et al } \\
{[2]}\end{array}$ & & - & & Advanced & & (+) CHR, SYN & - \\
\hline $\begin{array}{l}\text { Choi et al } \\
{[12]}\end{array}$ & $82 / \mathrm{F}$ & $\begin{array}{l}\text { Abdominal } \\
\text { discomfort }\end{array}$ & $6.7 \mathrm{~cm}$ & Advanced & 3.4 & $\begin{array}{l}\text { (+) CD56, NSE, SYN, } \\
\text { CHR,TTF-1, C-kit; } \\
\text { (-) Antihepatocyte, } \\
\text { AFP,vimentin, desmin, CK7, } \\
\text { 19, 20, CEA, S-100 protein }\end{array}$ & $\begin{array}{l}\text { Segmentectomy of } \\
\text { liver and } \\
\text { CT (etoposide) }\end{array}$ \\
\hline $\begin{array}{l}\text { Morikawa } \\
\text { et al [15] }\end{array}$ & 77/M & $\begin{array}{l}\text { General } \\
\text { fatigue and } \\
\text { breathlessness }\end{array}$ & $10 \mathrm{~cm}$ & Advanced & 27 & $\begin{array}{l}(+) \text { AE1/AE5, CAM5.2; } \\
\text { (-) NSE, desmin, vimentin, } \\
\text { CEA }\end{array}$ & $\begin{array}{l}\text { CT (cisplatin, } \\
\text { etoposide) }\end{array}$ \\
\hline $\begin{array}{l}\text { Yang- } \\
\text { Qing } \\
\text { Huang et } \\
\text { al [14] }\end{array}$ & $34 / \mathrm{M}$ & $\begin{array}{l}\text { Incidental } \\
\text { detection }\end{array}$ & & - & - & & $\begin{array}{l}\text { Right hepatectomy } \\
\text { and segment I } \\
\text { excision and TACE } \\
\text { for recurrance }\end{array}$ \\
\hline $\begin{array}{l}\text { Index } \\
\text { case }\end{array}$ & $40 / \mathrm{F}$ & $\begin{array}{l}\text { Pain and lump } \\
\text { abdomen }\end{array}$ & $13.5 \mathrm{~cm}$ & Advanced & 2.1 & $\begin{array}{l}\text { (+) NSE, SYN; } \\
\text { (-) TTF1, hep-par 1, CEA }\end{array}$ & $\begin{array}{l}\text { Central } \\
\text { bisectionectomy } \\
\text { and CT (cisplatin, } \\
\text { etoposide) }\end{array}$ \\
\hline
\end{tabular}

RUQ, Right upper quadrant; DM, Diabetes mellitus; CT, Chemotherapy; AFP, Alpha-fetoprotein; CEA, Carcinoembryonic antigen; CHR, Chromogranin; CK, Cytokeratin; EMA, Epithelial membrane antigen; NSE, Neuron-specific enolase; SYN, Synaptophysin; TTF-1, Thyroid transcription factor 1. 
small cell cancer of liver. But knowing the aggressive course of the tumor behavior, it is better to go for radical surgery and followed by combination chemotherapy.

\section{References}

1. Richardson RL, Weiland LH. Undifferentiated small cell carcinomas in extrapulmonary sites. Semin Oncol 1982;9(4):484-496.

2. Kim KO, Lee HY, Chun SH, Shin SJ, Kim MK, Lee KH, Hyun MS, et al. Clinical overview of extrapulmonary small cell carcinoma. J Korean Med Sci 2006;21(5):833837.

3. Frazier SR, Kaplan PA, Loy TS. The pathology of extrapulmonary small cell carcinoma. Semin Oncol 2007;34(1):30-38.

4. Duguid JB, Kennedy AM. Oat-cell tumors of mediastinal glands. J Pathol Bacteriol 1930; 33:93-9.

5. Galanis E, Frytak S, Lloyd RV. Extrapulmonary small cell carcinoma. Cancer 1997;79(9):1729-1736.

6. Vrouvas J, Ash DV. Extrapulmonary small cell cancer. Clin Oncol (R Coll Radiol) 1995;7(6):377-381.

7. van der Heijden HF, Heijdra YF. Extrapulmonary small cell carcinoma. South Med J 2005;98(3):345-349.

8. Zanconati F, Falconieri G, Lamovec J, Zidar A. Small cell carcinoma of the liver: a hitherto unreported vari- ant of hepatocellular carcinoma. Histopathology 1996;29(5):449-453.

9. Sengoz M, Abacioglu U, Salepci T, Eren F, Yumuk F, Turhal S. Extrapulmonary small cell carcinoma: multimodality treatment results. Tumori 2003;89(3):274-277.

10. Kim YH, Kwon R, Jung GJ, Roh MH, Han SY, Kwon $\mathrm{HC}$, Jeong JS, et al. Extrapulmonary small-cell carcinoma of the liver. J Hepatobiliary Pancreat Surg 2004;11(5):333-337.

11. Ryu SH, Han SY, Suh SH, Koo YH, Cho JH, Han SH, Lee SW, et al. [A case of primary small cell carcinoma of the liver]. Korean J Hepatol 2005;11(3):289-292.

12. Choi SJ, Kim JM, Han JY, Ahn SI, Kim JS, Kim L, Park IS, et al. Extrapulmonary small cell carcinoma of the liver: clinicopathological and immunohistochemical findings. Yonsei Med J 2007;48(6):1066-1071.

13. Kim KJ, Yim HJ, Kim MJ, Choung RS, Yeon JE, Lee HS, Byun KS, et al. [A case of primary small cell neuroendocrine carcinoma of the liver]. Korean J Gastroenterol 2006;48(1):37-41.

14. Huang YQ, Xu F, Yang JM, Huang B. Primary hepatic neuroendocrine carcinoma: clinical analysis of 11 cases. Hepatobiliary Pancreat Dis Int;9(1):44-48.

15. Morikawa H, Nakayama Y, Maeda T, Nadatani Y, Kobayashi S, Iwai S, Enomoto M, et al. A case of primary small cell carcinoma of the liver that was treated with chemotherapy. Hepatol Int 2008;2(4):500-504. 